\title{
ХРОНИКА
}

удК 94(5)

DOI: $10.22378 / 2313-6197.2017-5-2.474-477$

\section{MEDIEVAL NOMADS - SIXTH INTERNATIONAL CONFERENCE ON THE MEDIEVAL HISTORY OF THE EURASIAN STEPPE (SZEGED, HUNGARY, NOVEMBER 23-26, 2016)}

\author{
Aleksandar Uzelac \\ The Institute of History Belgrade \\ Belgrade, Serbia \\ aleksandar.uzelac@iib.ac.rs
}

\begin{abstract}
Sixth international conference dedicated to the Medieval History of the Eurasian Steppe took place in the Hungarian city of Szeged on November 23-26, 2016. The organizer of the event was MTA-SZTE ("Hungarian Academy of Sciences - University of Szeged") Turkological Research group of the departments of Altaic and Medieval Studies at the Faculty of Arts, University of Szeged. More than thirty scholars from Hungary, Russia, Turkey, China, Spain, Bulgaria and Serbia took part in this event. The working languages of the conference were English and Russian. Presented papers dealt with various aspects of the history of Eurasian nomads, from the Early Middle Ages up to the seventeenth century. Among them, several have been related to the history of the Golden Horde. The proceedings of the conference are planned to be published in 2017, as a separate volume of the journal Chronica - Annual of The Institute of History, University of Szeged. Considering the quality and variety of the papers, presented at this occasion, there is no doubt it will attract the attention of the growing community of researchers and scholars interested in the medieval history of Eurasia.
\end{abstract}

Keywords: international conference, medieval nomads of Eurasia, history of the Mongol empire, source study, archaeology

For citation: Uzelac A. Medieval Nomads - Sixth International Conference on the Medieval History of the Eurasian Steppe (Szeged, Hungary, November 23-26, 2016). Zolotoordynskoe obozrenie $=$ Golden Horde Review. 2017. Vol. 5, no. 2, pp. 474-477. DOI: 10.22378/2313-6197.2017-5-2.474-477

During the penultimate week of November 2016, Faculty of Arts in Szeged, Hungary, hosted an international conference dedicated to the Medieval History of the Eurasian Steppe. This traditional event was organized sixth time in a row since 2003 by MTA-SZTE ("Hungarian Academy of Sciences - University of Szeged") Turkological Research group of the departments of Altaic and Medieval Studies at the Faculty of Arts, University of Szeged, led by professors Mária Ivanics and István Zimony. More than thirty scholars from Hungary, Russia, Turkey, China, Spain, Bulgaria and Serbia took part in this event. The program was divided into eleven sessions, all of them followed by well prepared presentations and lengthy 
and fruitful discussions. The working languages of the conference were English and Russian.

Presented papers dealt with various aspects of the history of Eurasian nomads, from the Early Middle Ages up to the seventeenth century. Among them were those dedicated to the internal organization and political transformations of Eurasian peoples (Isenbike Togan, Changes in titulature and westward migration: the case of the Qarluqs; Nikolay Kradin, The Urbanization of Liao and Yuan empires in the Mongolian steppes; Hao Chen, Transformation of the concept 'toquz oghuz' in medieval Eurasia), military history (Mutlu Kahraman, Warfare of Turk Khanate), oral and written traditions (Balázs Danka, An epical geography of the Oguz-nāmä in Uygur script; Tatyana Anikeeva, Nomads in prose medieval Turkish folklore - Battal-name and Danishmend-name) geography (Tatyana Kalinina, The Turks on medieval Arab maps), diplomacy (Mehmet Tezcan, In which group are the Orkhon inscriptions classified in terms of diplomacy) and trade (Mátyás Balogh, On the emergence of the Qinghai sections of the Silk Road).

Three papers were focused on the contacts between Eastern Slavs and Turkic peoples in pre-Mongol Era (Марта Фонт, Южная Русь и ее соседи в 12-13 вв. в свете генеалогии; Csete Katona, Merge of cultures: steppe nomadic traits in Rus rituals; Vladimir Petrukhin, The title khagan in Old Slavic traditions), while four dealt with various aspects of the history of the Mongol Empire (Miklós Sárközy, Mongol-Nizārī Ismaili relations in Northern Iran before 1256 - new sources and results; Márton Vér, An Old Uyghur register and the different levels of administration of the Mongol Empire's postal system; Ishayahu Landa, Reconsidering the Chinggisids' son-in-laws: Lessons from the United Empire; Xiaolin Ma, The Eleven Queens' Ordos and Imperial Ancestral Sacrifice under the Mongol- Yuan Dynasty: from steppe to North China). Issues of power and authority in Post-Chingissid states were the subject of the two presentations that attracted wide attention of the participants (Alexander Vasilyev, The Ottoman document on the hierarchy of power in the dynasties of Shaibanids and Timurids according to the traditions of nomadic law; Татьяна Скрынникова, Символь власти в Монголии XVII в. по материалам летописи Erdeni tunumal neretü sudur).

Similar interest and discussion followed the papers oriented towards philological questions (István Fodor, On the historical background of the Bulgar-Turkic loanwords of the Hungarian language) and methodological aspects of the researches (Agustí Alemany, A prosopographical approach to medieval Eurasian nomads; Владимир Иванов - Марина Ивановна, Парадоксы источниковедения средневековых кочевников Восточной Европы; Szabolcs Polgár, The Proto-Hungarians from the perspective of the migrations of the Eurasian nomads). The archeologists, mostly Russian based scholars, offered several intriguing presentations related to the newest findings and field researches (Дмитрий Васильев, Стела Окуневской культуры из Хакасии с тюркской рунической надписью и тамгой кыргызских правителей; Николай Серегин, Алтай в раннетюркское время; Николай Рыбаков, Карта манихейских маршрутов в Центральной Азии: Юг-Север; Андрей Белявин - Наталья Крыласова, Взаимодействие Предуралья и населения салтово-маяџкой археологической культуpbl; Krisztina Hoppál, New shades of old materials. Changing roles of gold and glass artefacts in the barbarian states of China; Алексей Тишкин, Алтай в предтюркское время, по материалам исследований памятника Яломан-II). 
Last but not least, four papers presented at the conference were related to the history of the Golden Horde. Two Hungarian scholars affiliated with host institution provided insightful papers dealing with different groups of sources important for the Juchid history. Szilvia Kovács discussed activities of a Franciscan missionary, Hungarian friar Stephen, who was murdered in Sarai in 1334, providing in addition general overview of the minorite activities at the beginning of the fourteenth century (Sz. Kovács, An unremembered Hungarian Friar's martyrdom in the Golden Horde), while Csaba Göncöl analyzed place of the eponymous forefather of the clan Sirin in the work of famous eighteenth century writer Qirimi (Cs. Göncöl, Rüktemür Beg in the Chronicle of 'Abdu l-Ġaffār Q vrımi). Bulgarian historian Konstantin Golev discussed some aspects of the Battle of Kalka river (1223) and offered new hypotheses related to the accounts presented in the Russian chronicles and internal dissenssions between the Russian and the Cuman camp on the eve of the battle (K. Golev, The Battle of the Kalka River - a tentative reconstruction). Finally, the author of these words presented his paper focused on the ethnic and religious conditions in the western lands of the Golden Horde in the late thirteenth century, on the basis of Western, Slavic, Byzantine and Oriental Sources (A. Uzelac, An Empire within an Empire? - Ethnic, Religious and Demographic Realities in the Ulus of Nogai).

Invited by the organizers, participants of the conference visited Ferenc Móra Museum in Szeged on November 26. Particular interest was shown to the museum's permanent exhibition of the golden artefacts, including the collection from the Age of the Huns.

The proceedings of the conference are planned to be published in 2017, as a separate volume of the journal Chronica - Annual of The Institute of History, University of Szeged. Considering the quality and variety of the papers, presented at this occasion, there is no doubt that it will attract the attention of the growing community of researchers and scholars interested in the medieval history of Eurasia.

About the author: Aleksandar Uzelac - Ph.D. (History), Research Associate, The Institute of History Belgrade, ORCID: http://orcid.org/0000-0003-0626-2928 (36/II Kneza Mihaila Str., Belgrade 11000, Serbia). E-mail: aleksandar.uzelac@iib.ac.rs 
Aleksandar Uzelac. Medieval Nomads - Sixth International Conference...

\title{
СРЕДНЕВЕКОВЫЕ КОЧЕВНИКИ - \\ ШЕСТАЯ МЕЖДУНАРОДНАЯ КОНФЕРЕНЦИЯ, ПОСВЯЩЕННАЯ СРЕДНЕВЕКОВОЙ ИСТОРИИ ЕВРАЗИЙСКИХ СТЕПЕЙ \\ (СЕГЕД, ВЕНГРИЯ, 23-26 НОЯБРЯ, 2016 Г.)
}

\author{
Александар Узелац \\ Институт истории (Белград) \\ Белград, Сербия \\ aleksandar.uzelac@iib.ac.rs
}

Шестая международная конференция, посвященная средневековой истории Евразийских степей была проведена в венгерском городе Сегед 23-26 ноября 2016 г. Организатором этого мероприятия стала MTA-SZTE («Венгерская академия наук Университет Сегеда») Тюркологическая исследовательская группа отдела алтаистики и медиевистики Факультета искусств Сегедского университета. На конференции приняли участие более тридцати ученых из Венгрии, России, Турции, Китая, Испании, Болгарии и Сербии. Официальными языками конференции были английский и русский. Представленные доклады рассматривали различные аспекты истории и археологии кочевников от раннего средневековья до семнадцатого века. В том числе несколько докладов были связаны с историей, источниковедением и обществом Золотой Орды. Материалы конференции будут опубликованы в отдельном выпуске журнала Chronica - Annual of The Institute of History, University of Szeged. Учитывая качество и разнообразие представленных докладов, нет сомнений в том, что эта публикация привлечет внимание растущего сообщества исследователей и ученых, занимающихся средневековой историей Евразии.

Ключевые слова: международная конференция, средневековые кочевники Евразии, история Монгольской империи, источниковедение, археология

Для цитирования: Uzelac A. Medieval Nomads - Sixth International conference on the Medieval history of the Eurasian steppe (Szeged, Hungary, November 23-26, 2016) // Золотоордынское обозрение. 2017. Т. 5, № 2. С. 474-477. DOI: 10.22378/23136197.2017-5-2.474-477

Сведения об авторе: Александар Узелац - Ph.D. (история), научный сотрудник, Институт истории (Белград), ORCID: http://orcid.org/0000-0003-0626-2928 (11000, Кнеза Михаила, 36/II, Белград, Сербия). E-mail: aleksandar.uzelac@iib.ac.rs 